\title{
Estimation of zooplankton secondary production in estuarine waters: Comparison between the enzymatic (chitobiase) method and mathematical models using crustaceans
}

\author{
Tatiana Ramos Avila ${ }^{a}$, Anderson Abel de Souza Machado ${ }^{a}$, Adalto Bianchini ${ }^{\mathrm{b}, *}$ \\ a Universidade Federal do Rio Grande, Programa de Pós-Graduação em Oceanografia Biológica, Av. Itália km 8, 96201-00, Rio Grande, Rio Grande do Sul, Brazil \\ b Universidade Federal do Rio Grande, Instituto de Ciências Biológicas, Av. Itália km 8, 96201-900, Rio Grande, Rio Grande do Sul, Brazil
}

\section{A R T I C L E I N F O}

\section{Article history:}

Received 17 October 2011

Received in revised form 20 February 2012

Accepted 21 February 2012

Available online 28 March 2012

\section{Keywords:}

Chitobiase

Crustaceans

Growth

Secondary production

Zooplankton

\begin{abstract}
A B S T R A C T
Sampling was seasonally performed in the Patos Lagoon estuary (Rio Grande, RS, Southern Brazil) to estimate zooplankton biomass and production comparing values obtained using an enzymatic (chitobiase) method and the traditional mathematical models based on growth. Comparison of data obtained from zooplankton samples collected with 90 and 200- $\mu \mathrm{m}$ mesh nets showed that net selectivity influences the estimation of zooplankton biomass and production. Furthermore, it showed differential results for dominance of taxa and proportions of developmental stages in samples. Differences among samples collected at the different sites in the same season were observed using either the mathematical models or the enzymatic method. The two different approaches were also able to detect the seasonal variation in production. In a broad view, data obtained using the chitobiase method showed a similar pattern of zooplankton production compared to those obtained with the traditional mathematical models based on growth. However, values estimated using the enzymatic method were systematically higher than those obtained with the mathematical models. Maximum total production values were estimated as $12.5,9.2$ and $7.9 \mathrm{mg} \mathrm{C} \mathrm{m}^{-3}$ day $^{-1}$ for the "chitobiase method", "Huntley model", and "Hirst model", respectively. Considering all sampling sites and seasons, the magnitude of this difference corresponded to 1.95 and $2.49 \mathrm{mg} \mathrm{C} \mathrm{m}^{-3}$ day $^{-1}$ for the "Huntley model" and the "Hirst model", respectively. These findings indicate the reliability of the enzymatic method in estimating crustacean production also in estuarine environments of changing salinity, as previously demonstrated for marine waters. In addition, the use of this method is more practical and comparatively less time-consuming and cheaper than the use of the mathematical models based on growth.
\end{abstract}

(c) 2012 Elsevier B.V. All rights reserved.

\section{Introduction}

Production can be defined as the amount of tissue or biomass generated in a certain area within a period of time, being expressed as $\mathrm{mg} \mathrm{C} \mathrm{m}{ }^{-3} \mathrm{day}^{-1}$ (Rigler and Downing, 1984). Estimations of production are generally obtained using the equation $\mathrm{P}=\mathrm{B} \times \mathrm{g}$, where " $\mathrm{P}$ " is production, "B" biomass in the environment, and " $\mathrm{g}$ " growth rate (Huntley and Lopez, 1992; Kimmerer, 1987).

Considering that planktonic animals are the major link between primary producers and the higher trophic levels (Hopcroft and Roff, 1998), the estimation of the secondary production in aquatic environments is essential for the study of the energy flux through food chains. Although zooplankton is composed of animals from several taxonomic groups, crustaceans are generally dominants. In fact,

\footnotetext{
* Corresponding author at: Universidade Federal do Rio Grande, Instituto de Ciências Biológicas, Av. Itália km 8, Campus Carreiros, 96201-900, Rio Grande, Rio Grande do Sul, Brazil. Tel.: +55 53 32935193; fax: + 555332336633 .

E-mail address: adaltobianchini@furg.br (A. Bianchini).
}

copepods often contribute with the major part of the zooplankton biomass and species diversity in estuaries (Kleppel et al., 1988).

Methods for zooplankton biomass estimation are relatively standardized and biomass values are reported for different areas worldwide. However, data are generally obtained from samples collected with nets of mesh diameter ranging from 64 to $300 \mu \mathrm{m}$ (Magalhães et al., 2006; Purcell et al., 1994). It is important to note that net selectivity could have a significant influence on data generated, since it can differentially represent the dominant species and/or the proportion of developmental stages present in the environment. In addition, the methodology employed to determine the animal growth rate represents the major problem in the production estimation process.

Research efforts on zooplankton growth rate are focused on copepods in marine environments and on copepods and cladocerans in freshwater, since these groups are dominants in their environments. Growth estimation is generally based on weight-specific egg production (Hirst and McKinnon, 2001), cohort analysis (Kang et al., 2007), and physiological models (Ikeda et al., 2001). Growth rates are usually determined based on data from laboratory experiments. Therefore, they are derived only for a single species or a few species present in 
the environment, since this approach is highly time-consuming. Consequently, a high-resolution estimation of production considering a temporal and spatial frame is quite difficult to perform.

With the goal of developing alternative methods to facilitate the secondary production estimation, some mathematical models were developed to estimate zooplankton growth rate $(g)$ based on data reported for marine copepods (Hirst and Bunker, 2003; Huntley and Lopez, 1992) and freshwater crustaceans (Stockwell and Johannsson, 1997). It is important to stress that each model differently considers the degree of influence of temperature, food deprivation, and size of organisms as factors affecting growth rate.

Other methods less employed for secondary production estimation are those based on the relationship between the activities of enzymes involved in molting, such as chitobiase, and the growth of crustaceans (Biegala and Bergeron, 1998). Based on previous studies (Espie and Roff, 1995; Oosterhuis et al., 2000), Sastri and Dower (2006, 2009) described a method for estimation of secondary production based on the amount of chitobiase released in the water during the crustacean molting process. The rationale behind this method is the existence of a relationship between the dried mass increment observed after growth from the molting stage " $x$ " to the " $x+1$ " and the enzyme activity in the water. This method also considers the existence of a balance over time between the activity generated due to the enzyme released by the zooplankton population and the natural enzyme degradation in the field. In fact, tests performed in laboratory with freshwater cladocerans (Sastri and Roff, 2000) and marine copepods like Temora longicornis (Oosterhuis et al., 2000), Calanus pacificus, Metridia pacifica and Pseudocalanus spp. (Sastri and Dower, 2006) showed the existence of a positive correlation between the chitobiase activity in the water and the size and biomass of organisms. This relationship was also demonstrated for decapod and mysid larvae (Sastri and Dower, 2009), indicating that the chitobiase method can potentially account the overall production generated by crustaceans in the water column during the growth period.

Unlike from the environments where the chitobiase method was already applied for secondary production estimation, i.e., low temperatures and water salinities averaging $31 \mathrm{ppt}$, the estuarine waters from the Patos Lagoon (Rio Grande, RS, Southern Brazil) are often subjected to frequent and wide changes in temperature $\left(15-30{ }^{\circ} \mathrm{C}\right)$ and salinity (0-30) over an annual basis (Niencheski et al., 1986). Due to the extreme changes in environmental parameters, biota living in the Patos Lagoon estuary is characterized by a low diversity and the frequent dominance of species adapted to these changes, with occurrence alternating between marine and freshwater species. A dominance of the copepod Acartia tonsa has been historically reported to occur during periods of saltwater intrusion in the Patos Lagoon estuary. However, the copepod Notodiaptomus incompositus dominates the zooplankton community during freshwater runoff periods (Montú, 1980).

With this background in mind, the present study was performed to evaluate the influence of net selectivity on abundance and biomass of juvenile copepods, as well as the influence of these biotic parameters on the secondary production estimation. Additionally, the reliability of the chitobiase method was tested for a complex estuarine environment (Patos Lagoon estuary) by comparing the secondary production values estimated using this enzymatic method and those generated using the mathematical growth models described by Huntley and Lopez (1992) and Hirst and Bunker (2003) for organisms living in high salinity waters, and by Stockwell and Johannsson (1997) for freshwater animals.

\section{Material and methods}

\subsection{Estimation of secondary production based on mathematical models}

The Patos Lagoon estuary $\left(32^{\circ} \mathrm{S} ; 52^{\circ} \mathrm{W}\right)$ shows a diversity of habitats, including large shallow areas and a deep canal. Water circulation in the estuary is driven by wind and salinity changes according to the intrusion of coastal marine waters and the volume of freshwater discharged into the lagoon towards the Atlantic Ocean (Möller et al., 2001). Considering this diversity of habitats, five different collection sites were selected for the present study: ME (Mangueira enclosure), EM (estuary mouth), WM (west margin of the estuary), NC (navigation channel), and YC (Yatch Club enclosure) (Fig. 1).

In each season (25 August 2009, 29 October 2009, 13 January 2010 and 06 April 2010), one sample was collected per site for zooplankton analysis. Sampling was performed by horizontal towing at the surface water using a bongo plankton net $(0.3 \mathrm{~m}$ mouth diameter; 90 and $200-\mu \mathrm{m}$ mesh). A flow meter (Hydro-Bios Kiel, Altenholz, Germany) was attached to the net mouth for water flux measurements. Immediately after collection, organisms captured were preserved in $4 \%$ formaldehyde solution neutralized with sodium tetraborate. These samples were used for determination of the abundance of larval stages and biomass of copepods and cladocerans.

In the laboratory, sample aliquots containing at least 300 individuals were counted, identified under stereoscopic microscope (Olympus BH2, Center Valley, Pennsylvania, USA), and classified according to Montú and Gloeden (1986) and Bradford-Grieve et al. (1999). Calanoid copepods were classified by stages (nauplius, copepodite and adult). Cyclopoid copepods and cladocerans were identified at the genus level.

Production of marine copepods was calculated using the instantaneous growth method defined by the relationship among production $(\mathrm{P})$, biomass $(\mathrm{B})$ and growth rate $(\mathrm{g})$ following the formula $\mathrm{P}=\mathrm{B} \times \mathrm{g}$ (Rigler and Downing, 1984). In the present study, "total biomass" of copepods in the sample (B) was determined by the sum of the biomass obtained for each developmental stage [density of individuals in $i$ stage (individuals $\mathrm{m}^{-3}$ ) $\times$ body mass of the individual $\left.i(\mu \mathrm{g} \mathrm{C})\right]$. Growth rates were estimated using the equations proposed by Huntley and Lopez (1992) and Hirst and Bunker (2003). For freshwater copepods and cladocerans, production values were calculated using the model described by Stockwell and Johannsson (1997) (Table 1). For each sampling site, production of freshwater organisms was added to that estimated by the "Huntley and Lopes" model or the "Hirst and Bunker" model. In the Results section, values are thus referred as "Huntley model" (estimation using "Huntley and Lopes" + "Stockwell and Johannsson" models) and "Hirst model" (estimation using "Hirst and Bunker" + "Stockwell and Johannsson" models).

"Total production" was calculated adding the biomass of each taxonomic group. For this purpose, the biomass value adopted corresponded to that originating from the sample showing the higher relative abundance for the respective taxonomic group, disregarding the net mesh used for collection. Similarly, the "juvenile production" was also calculated based on the sum of biomass of the juvenile stages found in the sample. The biomass value adopted for each stage corresponded to that originating from the sample showing the higher relative abundance for the respective stage, disregarding the net mesh used for collection. In both cases, values represented the production closer to the "ideal" conditions for calculations based on preserved samples.

For all mathematical models employed, a biomass value for each sample was obtained considering the more abundant copepod and cladoceran species present in the respective sample. Biomass values were obtained through body length measurements and application of the relationships existing between body length and body mass for each respective taxonomic group (Table 1 ).

For the Hirst and Bunker (2003) model, chlorophyll- $a$ values were obtained from data generated by the "Projeto Lagoa" ("Lagoon Project") and kindly provided by the Phytoplankton Laboratory of the University (Institute of Oceanography, Federal University of Rio Grande - FURG). In the present study, mean seasonal values of chlorophyll- $a$ were used. They corresponded to 3.9, 2.6, 2.4 and $1.3 \mu \mathrm{g} \mathrm{L}^{-1}$ for winter, spring, summer and autumn, respectively.

For the Stockwell and Johannsson (1997) model, the individual body mass $(\mathrm{M})$ was obtained from the relationships reported by 


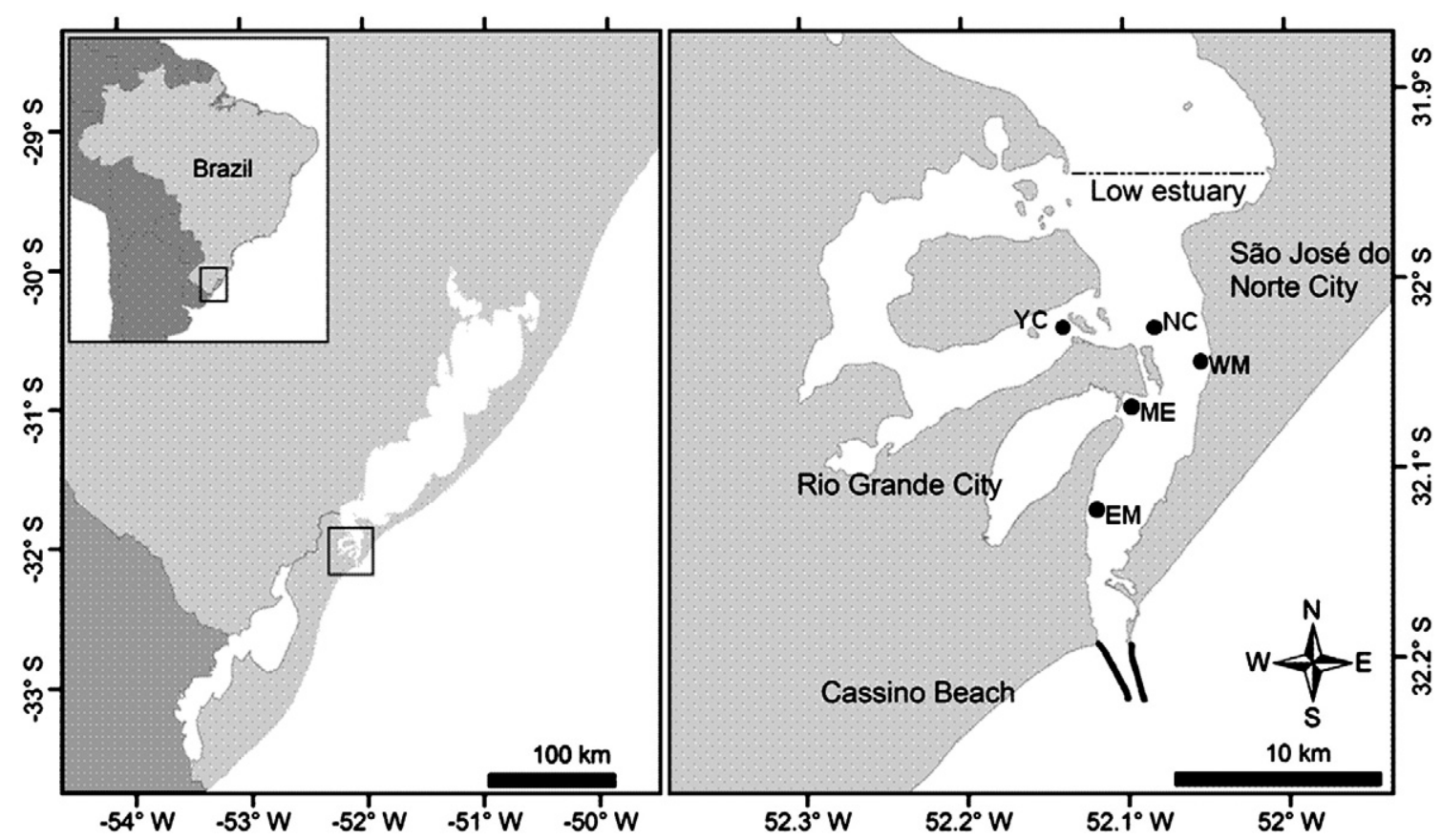

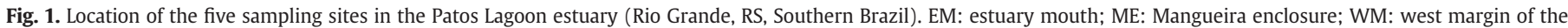
estuary; NC: navigation channel; YC: Yatch Club enclosure.

McCauley (1984) based on the mean body length of individuals from each cladoceran genus identified and counted in the samples collected in the present study (Table 1). In equations where the biomass is estimated based on dry mass, the correction factor of 0.4 was used to convert dry mass in the amount of carbon (Postel et al., 2000).

\subsection{Estimation of secondary production based on the chitobiase (enzymatic) method}

Estimation of secondary production using the enzymatic method was performed based on the existing relationship between the chitobiase activity measured in the environment (native chitobiase; $\mathrm{CBA}_{\text {nat }}$ ) and the rate of enzyme activity decay in the field (Sastri and Dower,
2009). The estimate also considered the existing relationship between the activity of the enzyme released during the molting process (CBA) and the increment in biomass from the $x$ stage to the $x+1$ stage $(\Delta \mathrm{B})$, which was measured in laboratory. Secondary production ( $\mathrm{P}$; expressed

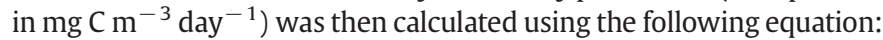
$\mathrm{P}=\Delta \mathrm{B} / \mathrm{Tcb}$, where $\Delta \mathrm{B}$ is the biomass increment in the environment and Tcba the time (days) necessary to generate this biomass.

\subsubsection{Relationship between the increment in dry mass $(\triangle B)$ and enzyme activity (CBA)}

According to previous reports on the zooplankton composition in the Patos Lagoon estuary, the copepod A. tonsa was identified as

Table 1

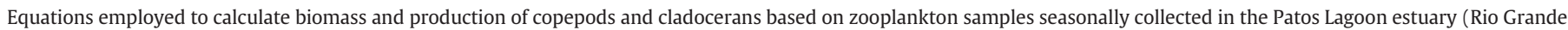
RS, Southern Brazil).

\begin{tabular}{|c|c|c|c|}
\hline & Equation & Reference & Definition of equation terms \\
\hline \multicolumn{4}{|c|}{ Freshwater organisms } \\
\hline Biomass & $\mathrm{B}=\mathrm{a} \cdot \mathrm{L}^{\mathrm{b}}$ & 1 & B: biomass (mg dry weight) \\
\hline \multicolumn{3}{|c|}{ Daphnia spp. $(\mathrm{a}=6.00 ; \mathrm{b}=3.62)$} & a, b: specific alometric coefficients \\
\hline \multicolumn{3}{|c|}{ Diaphanosoma spp. $(\mathrm{a}=6.95 ; \mathrm{b}=2.07)$} & L: body length (mm) \\
\hline \multicolumn{4}{|c|}{ Bosmina spp. $(\mathrm{a}=15.10 ; \mathrm{b}=2.53)$} \\
\hline \multicolumn{4}{|c|}{ Cyclopoida $(\mathrm{a}=4.18 ; \mathrm{b}=2.64)$} \\
\hline \multicolumn{4}{|c|}{ Calanoida $(\mathrm{a}=6.81 ; \mathrm{b}=2.11)$} \\
\hline \multicolumn{4}{|c|}{ Nauplii $(\mathrm{a}=1.64 ; \mathrm{b}=0.57)$} \\
\hline \multirow[t]{3}{*}{ Production } & $\mathrm{P}=10^{(\mathrm{a} \cdot \log 10 \mathrm{M}+\mathrm{b})}$.CF.M.N & 2 & CF: correction factor $=1.12($ Sprugel, 1983$)$ \\
\hline & & & M: mean dry body weight $(\mu \mathrm{g})$ \\
\hline & & & $\begin{array}{l}\mathrm{N} \text { : abundance of stage in the sample } \\
\mathrm{a}=-0.23 ; \mathrm{b}=-0.73\end{array}$ \\
\hline \multicolumn{4}{|c|}{ Estuarine and marine organisms } \\
\hline \multirow[t]{2}{*}{ Biomass } & $\log C=3.319 . \log \mathrm{TL}-8.519$ & 3 & C: carbon $(\mu \mathrm{g})$ \\
\hline & $\log \mathrm{C}=2.919 . \log \mathrm{PL}-7.953$ & 3 & TL: total length of nauplii ( $\mu \mathrm{m})$ \\
\hline \multirow[t]{5}{*}{ Growth } & $g=0.0445 . e^{0.111 \mathrm{~T}}$ & 4 & PL: copepodite/adult prosome length $(\mu \mathrm{m})$ \\
\hline & $\log _{10} g=\mathrm{a}[\mathrm{T}]+\mathrm{b}\left[\log _{10} \mathrm{BW}\right]$ & 5 & T: temperature $\left({ }^{\circ} \mathrm{C}\right)$ \\
\hline & $+\mathrm{c}\left[\log _{10} \mathrm{Cl}-a\right]+\mathrm{d}$ & & BW: body weight \\
\hline & & & Cl- $a$ : chlorophyll- $a$ \\
\hline & & & $\begin{array}{l}\text { a, b, c, d: coefficients depending on life stage and } \\
\text { spawning strategy (free or sac) }\end{array}$ \\
\hline Production & $\mathrm{P}=\mathrm{B} . \mathrm{g}$ & & B: biomass; $g$ : growth rate \\
\hline
\end{tabular}

1. McCauley (1984); 2. Stockwell and Johannsson (1997); 3. Berggreen et al. (1988); 4. Huntley and Lopez (1992); 5. Hirst and Bunker (2003). 
being the major representative of crustaceans. Therefore, this copepod species was employed for the molting experiments in laboratory.

The enzyme activity from chitobiase released during the molting process of each $A$. tonsa copepodite stage was determined after incubation of individuals at the respective life stage in $200 \mu$ of seawater (salinity $30 \mathrm{ppt}$ ). Experimental medium was previously autoclaved and filtered (polycarbonate filter; $0.2-\mu \mathrm{m}$ mesh filter) to eliminate bacteria and other microorganisms that can influence the rate of enzyme activity decay (Oosterhuis et al., 2000). Every 2 h, copepods were observed under the microscope to identify the molted ones. Activity of chitobiase released was measured in water samples $(150 \mu \mathrm{l})$ collected from the incubation medium, as described below. Both copepods and exuviae were preserved (4\% formaldehyde solution neutralized with sodium tetraborate) for further measurement and calculation of biomass using the relationship between the cephalotorax length and dry mass (Berggreen et al., 1988).

The parameter $\Delta \mathrm{B}$ was calculated from the difference in the dry mass between the stages $x$ and $x+1$. A natural log transformation was applied to the enzyme activity and $\Delta B$ values, which were subjected to regression analysis. The equation $\ln (C B A)=a \ln (\Delta B)+b$ was further employed to determine the secondary production in the Patos Lagoon estuary by replacing the term $\mathrm{CBA}$ by the $\mathrm{CBA}_{\text {nat }}$ value for each data point. The $\Delta \mathrm{B}$ value ( $\mu$ g dry mass) added to the environment in the respective period of time was then calculated. The period of time (Tcba) was determined from the rate of enzyme activity decay in the field (Sastri and Dower, 2009).

\subsubsection{Estimation of secondary production in the field based on the chitobiase activity}

Secondary production in the Patos Lagoon estuary was estimated based on the chitobiase method for the five sampling sites described above. In each sampling site, $300 \mathrm{~mL}$ of surface water was collected, filtered (30- $\mu \mathrm{m}$ mesh filter) to remove crustaceans, and stored in glass vials. Aliquots of these samples were filtered $(0.02-\mu \mathrm{m}$ mesh sterile filter) and frozen in glass vials. These water aliquots were labeled as "Native Chitobiase" $\left(\mathrm{CBA}_{\text {nat }}\right)$. The remaining sample was employed for determination of the rate of enzyme activity decay over time.

The enzyme activity decay assay was performed using a concentrated solution of chitobiase obtained after homogenization of 50 individuals of the dominating species in the respective sampling site. Homogenates were centrifuged ( $5 \mathrm{~min} ; 10,000 \times \mathrm{g}$ ) and the supernatant obtained was filtered ( $0.2-\mu \mathrm{m}$ mesh filter). The concentrated solution containing the enzyme was added to the water samples collected at the five sampling sites in the Patos Lagoon estuary. Reaction flasks were kept at the same temperature as the ambient water. Aliquots of the reaction medium were then collected over the $24 \mathrm{~h}$ of the test. These aliquots were filtered and frozen as described above for the $\mathrm{CBA}_{\text {nat }}$ samples. Enzyme activity values were log transformed and a regression line between enzyme activity and reaction time was built. The regression slope value $(k)$ corresponded to the enzyme activity decay. Therefore, $-1 / k$ was applied to determine the time $(h)$ to generate $\Delta \mathrm{B}$ (i.e., Tcba). The Tcba value derived was divided by $24 \mathrm{~h}$ to express data in days.

\subsubsection{Chitobiase assay}

Chitobiase activity was measured following the method described by Oosterhuis et al. (2000) and Sastri and Dower (2006) with some modifications (Avila et al., 2011). Briefly, the substrate methylumbelliferyl N-acetyl-ß-D-glucosaminide (MUFNAG, Sigma, St. Louis, MO, USA) was used for the enzyme assay. A stock solution ( 9 mM MUFNAG) was prepared dissolving MUFNAG in dimethylsulfoxide. For enzyme assays, the stock solution was diluted to give a final concentration of $250 \mu \mathrm{M}$ MUFNAG. Assay tubes were filled with water samples $(486 \mu \mathrm{l})$ and dilute MUFNAG $(14 \mu \mathrm{l})$. Controls were also run using autoclaved and filtered (polycarbonate filter; 0.2- $\mu \mathrm{m}$ mesh filter) seawater
(30 ppt) without addition of the enzyme source and/or the substrate (MUFNAG).

Chitobiase reaction with the substrate (MUFNAG) released the fluorescent methylumbelliferone (MUF). The enzymatic reaction was performed in 5-mL assay tubes and aliquots of the reaction medium were transferred to a 96-wells microplate for fluorescence readings (excitation: $360 \mathrm{~nm}$; emission: $450 \mathrm{~nm}$ ) using a spectrofluorometer (Hitachi F-2000; Tokyo, Japan). Fluorescence readings were performed every $5 \mathrm{~min}$ up to $60 \mathrm{~min}$ at $25^{\circ} \mathrm{C}$. Increment in fluorescence over time corresponded to the free chitobiase activity in the water and was expressed as the amount of MUF produced per hour (nmol MUF $\mathrm{L}^{-1} \mathrm{~h}^{-1}$ ). Data were calculated based on a calibration curve built with different concentrations of 4-methylumbelliferone (Sigma, St. Louis, MO, USA). As water salinity influences the fluorescence generated by MUF and chitobiase activity, results were corrected as described by Avila et al. (2011).

\subsection{Comparison among methods of secondary production estimation}

Comparison among the mean total production values estimated using the mathematical models based on growth and the enzymatic (chitobiase) method was performed through regression analyses using the software Statistica version 6.0 (Statsoft, USA).

\section{Results}

Depth of sampling sites used in the present study ranged from 4 to $12 \mathrm{~m}$. Water temperature and salinity did not change significantly among sites within the same season, but showed significant seasonal variations. Minimum and maximum temperatures observed were 16 and $25^{\circ} \mathrm{C}$, respectively. Minimum and maximum salinity were 0 and $4 \mathrm{ppt}$, respectively. The lower water $\mathrm{pH}$ was found in the winter ( $\mathrm{pH}$ 6.5). The mean $\mathrm{pH}$ in the other seasons was 7.6 (Table 2).

\subsection{Zooplankton biomass}

Biomass for each taxonomic group studied showed significant changes among seasons and sampling sites within the same season. The copepod $A$. tonsa represented virtually $100 \%$ of the zooplankton biomass in the winter. However, it was not found in spring and summer, being replaced by the copepod $N$. incompositus and cladocerans. Cladocerans and Cyclopoida copepods were identified at the genus level. However, they were grouped for analyses of biomass and production.

In winter, $A$. tonsa showed the highest biomass $\left(24.57 \mathrm{mg} \mathrm{C} \mathrm{m}^{-3}\right)$ at the WM site when the $200-\mu \mathrm{m}$ mesh net was used. The minimum value corresponded to $1.3 \mathrm{mg} \mathrm{C} \mathrm{m}^{-3}$ at the NC site using the $90-\mu \mathrm{m}$ mesh net. In autumn, the maximum biomass was also found for $A$. tonsa $\left(0.92 \mathrm{mg} \mathrm{C} \mathrm{m}^{-3}\right)$, but at the ME site using the $90-\mu \mathrm{m}$ mesh net. In spring, the copepod $N$. incompositus and cladocerans showed the highest biomass values (12.04 and $10.02 \mathrm{mg} \mathrm{C} \mathrm{m}^{-3}$, respectively). Although these organisms showed the higher biomass in the summer, maximum values were only 2.03 and $1.38 \mathrm{mg} \mathrm{C} \mathrm{m}^{-3}$ (Table 3).

\section{Table 2}

Characteristics of the five sampling sites (SS) at the Patos Lagoon estuary (Rio Grande, RS, Southern Brazil) in different seasons (WI: winter; SP: spring; SU: summer; AU: autumn). ME: Mangueira enclosure; EM: estuary mouth; WM: west margin of the estuary; NC: navigation channel; YC: Yatch Club enclosure.

\begin{tabular}{|c|c|c|c|c|c|c|c|c|c|c|c|c|c|}
\hline \multirow[t]{2}{*}{ SS } & \multirow{2}{*}{$\begin{array}{l}\text { Depth } \\
\text { (m) }\end{array}$} & \multicolumn{4}{|c|}{ Temperature $\left({ }^{\circ} \mathrm{C}\right)$} & \multicolumn{4}{|c|}{ Salinity (ppt) } & \multicolumn{4}{|l|}{$\mathrm{pH}$} \\
\hline & & WI & SP & SU & $\mathrm{AU}$ & WI & SP & SU & $\mathrm{AU}$ & WI & SP & SU & $\mathrm{AU}$ \\
\hline ME & 5 & 16 & 21 & 26 & 25 & 4 & 0 & 0 & 4 & 6.4 & 7.6 & 7.2 & 7.8 \\
\hline EM & 12 & 16 & 21 & 26 & 25 & 4 & 0 & 0 & 4 & 6.5 & 7.6 & 7.6 & 7.7 \\
\hline WM & 7 & 16 & 21 & 26 & 25 & 4 & 0 & 0 & 4 & 6.3 & 7.5 & 7.4 & 7.8 \\
\hline NC & 12 & 16 & 21 & 26 & 25 & 4 & 0 & 0 & 4 & 6.5 & 7.4 & 7.6 & 7.6 \\
\hline YC & 4 & 16 & 21 & 26 & 25 & 4 & 0 & 0 & 4 & 6.5 & 7.4 & 7.3 & 7.6 \\
\hline
\end{tabular}


Table 3

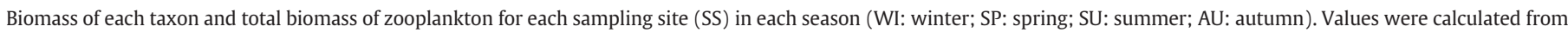

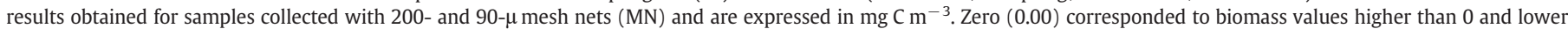
than $0.003 \mathrm{mg} \mathrm{C} \mathrm{m}^{-3}$. EM: estuary mouth; ME: Mangueira enclosure; NC: navigation channel; WM: west margin of the estuary; YC: Yatch Club enclosure.

\begin{tabular}{|c|c|c|c|c|c|c|c|c|c|c|c|}
\hline \multirow{2}{*}{$\frac{\mathrm{SS}}{\mathrm{MN}}$} & & \multicolumn{2}{|l|}{ EM } & \multicolumn{2}{|l|}{$\mathrm{ME}$} & \multicolumn{2}{|l|}{$\mathrm{NC}$} & \multicolumn{2}{|l|}{ WM } & \multicolumn{2}{|l|}{ YC } \\
\hline & & 200 & 90 & 200 & 90 & 200 & 90 & 200 & 90 & 200 & 90 \\
\hline \multirow[t]{5}{*}{ WI } & A. tonsa & 9.24 & 8.07 & 17.08 & 3.58 & 3.54 & 1.39 & 24.57 & 10.24 & 11.93 & 4.18 \\
\hline & N. incompositus & 0.04 & 0.31 & 0.21 & - & - & - & 0.59 & 0.18 & 0.59 & 0.41 \\
\hline & Cladocera & 0.01 & 0.03 & 0.02 & - & 0.18 & 0.04 & 0.11 & 0.07 & - & - \\
\hline & Cyclopoida & 0.01 & 0.06 & 0.02 & 0.02 & 0.02 & 0.02 & 0.02 & 0.04 & 0.01 & 0.03 \\
\hline & Total & 9.30 & 8.47 & 17.33 & 3.60 & 3.74 & 1.45 & 25.29 & 10.53 & 12.53 & 4.62 \\
\hline \multirow[t]{5}{*}{ SP } & A. tonsa & - & - & - & - & - & - & - & - & - & - \\
\hline & N. incompositus & 12.04 & 1.98 & 11.18 & 1.20 & 0.29 & 0.30 & 0.47 & 0.75 & 1.16 & 1.80 \\
\hline & Cladocera & 5.39 & 0.29 & 10.02 & 1.78 & 0.03 & 0.01 & - & - & 2.85 & 7.23 \\
\hline & Cyclopoida & 0.95 & 0.70 & 3.80 & 1.79 & 0.01 & - & 0.03 & 0.08 & 0.29 & 1.49 \\
\hline & Total & 18.38 & 2.97 & 25.00 & 4.77 & 0.33 & 0.31 & 0.50 & 0.83 & 4.30 & 10.52 \\
\hline \multirow[t]{5}{*}{ SU } & A. tonsa & - & - & - & - & - & - & - & - & - & - \\
\hline & N. incompositus & 0.12 & 0.77 & 0.93 & 1.57 & 0.07 & 0.00 & 0.16 & 0.85 & 1.33 & 2.03 \\
\hline & Cladocera & 0.22 & 0.81 & 0.51 & 1.26 & 0.92 & 0.08 & 0.41 & 0.82 & 0.71 & 1.38 \\
\hline & Cyclopoida & 0.02 & 0.18 & 0.07 & 0.16 & 0.03 & 0.00 & - & 0.04 & - & 0.30 \\
\hline & Total & 0.36 & 1.76 & 1.51 & 2.99 & 1.02 & 0.08 & 0.57 & 1.71 & 2.04 & 3.71 \\
\hline \multirow[t]{5}{*}{$\mathrm{AU}$} & A. tonsa & 0.64 & 0.77 & 0.59 & 0.92 & 0.23 & 0.25 & 0.07 & 0.08 & 0.20 & 0.02 \\
\hline & N. incompositus & 0.02 & 0.10 & 0.13 & 0.03 & 0.08 & 0.13 & 0.03 & 0.03 & 0.04 & 0.04 \\
\hline & Cladocera & 0.03 & 0.03 & 0.04 & 0.01 & 0.01 & 0.01 & 0.01 & 0.01 & 0.02 & 0.01 \\
\hline & Cyclopoida & 0.00 & 0.01 & 0.02 & 0.01 & 0.04 & 0.07 & 0.01 & 0.00 & 0.04 & 0.01 \\
\hline & Total & 0.69 & 0.91 & 0.78 & 0.97 & 0.36 & 0.46 & 0.12 & 0.12 & 0.30 & 0.07 \\
\hline
\end{tabular}

During the whole period of study, the highest biomass values were found in winter $\left(25.29 \mathrm{mg} \mathrm{C} \mathrm{m}^{-3}\right)$ and spring $\left(24.98 \mathrm{mg} \mathrm{C} \mathrm{m}^{-3}\right.$ ) with annual mean values of 13.64 and $9.7 \mathrm{mg} \mathrm{C} \mathrm{m}^{-3}$, respectively. The lowest value was observed in autumn $\left(0.07 \mathrm{mg} \mathrm{C} \mathrm{m}^{-3}\right)$ with a mean annual value of $0.5 \mathrm{mg} \mathrm{C} \mathrm{m}^{-3}$.

\subsection{Net selectivity}

The different selectivity of nets (90 and 200- $\mu \mathrm{m}$ mesh nets) employed in the present study reflected in different values of biomass calculated for samples from the same site of collection. For example, biomass values for $A$. tonsa collected in winter at the ME site corresponded to 3.58 and $17.08 \mathrm{mg} \mathrm{C} \mathrm{m}^{-3}$ for the 90 - and $200-\mu \mathrm{m}$ mesh nets, respectively. Biomass values for cladocerans collected in spring at the YC site corresponded to 7.23 and $2.85 \mathrm{mg} \mathrm{C} \mathrm{m}^{-3}$ for the 90and $200-\mu \mathrm{m}$ mesh nets, respectively (Table 3 ). For all taxa analyzed, net selectivity influenced the estimation of biomass, with higher mean values for the 200- $\mu \mathrm{m}$ mesh net in three seasons (Table 4).

Net selectivity also influenced the copepodite and nauplius density results. Depending on the developmental stage of copepodite, they were more captured by one or another net. However, as expected, nauplii showed higher density in all samples collected with the 90$\mu \mathrm{m}$ mesh net than in those collected with the 200- $\mu \mathrm{m}$ mesh net. In some sites where nauplii were not found in samples collected with the $200-\mu \mathrm{m}$ mesh net, density reached values as high as 2343 individuals $\mathrm{m}^{-3}$ (Table 5).

\section{Table 4}

Mean biomass for each season calculated based on results from samples collected with nets of different mesh size (200 and $90 \mu \mathrm{m}$ ) and mean production calculated using the "Huntley model", the "Hirst model" and the "chitobiase method" for the zooplankton of the Patos Lagoon estuary (Rio Grande, RS, Southern Brazil).

\begin{tabular}{|c|c|c|c|c|c|c|c|}
\hline \multirow[b]{3}{*}{ Net mesh $(\mu \mathrm{m})$} & \multirow{2}{*}{\multicolumn{2}{|c|}{$\begin{array}{l}\text { Mean } \\
\text { biomass } \\
\left(\mathrm{mg} \mathrm{C} \mathrm{m}^{-3}\right)\end{array}$}} & \multicolumn{5}{|c|}{ Mean production $\left(\mathrm{mg} \mathrm{C} \mathrm{m}^{-3} \mathrm{day}^{-1}\right)$} \\
\hline & & & \multicolumn{2}{|c|}{$\begin{array}{l}\text { Huntley } \\
\text { model }\end{array}$} & \multicolumn{2}{|c|}{ Hirst model } & \multirow[t]{2}{*}{ Chitobiase } \\
\hline & 200 & 90 & 200 & 90 & 200 & 90 & \\
\hline Winter & 13.64 & 5.73 & 4.35 & 1.80 & 3.84 & 2.45 & 5.55 \\
\hline Spring & 9.70 & 3.88 & 3.51 & 1.20 & 2.07 & 0.85 & 7.08 \\
\hline Summer & 1.10 & 2.05 & 0.56 & 1.12 & 0.22 & 0.52 & 3.87 \\
\hline Autumn & 0.44 & 0.50 & 0.30 & 0.35 & 0.05 & 0.18 & 2.35 \\
\hline
\end{tabular}

\subsection{Chitobiase activity}

For the copepod $A$. tonsa, the relationship between the biomass increment from the stage $x$ to the stage $x+1(\Delta \mathrm{B})$ and the activity of the enzyme released during the molting process $(\mathrm{CBA})$ was represented by the equation $\ln (\triangle \mathrm{B})=0.8876+0.5847 \times \ln (\mathrm{CBA}) \quad\left(r^{2}=0.98\right.$; $p<0.05 ; n=47$ molted copepods) (Fig. 2).

Fig. 3 shows the transformed $[\ln (\mathrm{x})]$ data of chitobiase activity over time for each collection site in spring. The Tcba values were calculated from the regression slope $(k)$ for each collection site. The same procedure was adopted for all samples collected for the determination of the secondary production using the enzymatic method.

\subsection{Zooplankton production for the different estimation methods}

Differences among samples collected at the different sampling sites in the same season were observed using either the mathematical models or the enzymatic method. The two different approaches were also able to detect the seasonal variation in production (Fig. 4).

Regarding the mathematical models, values estimated by the "Huntley model" were generally higher than those estimated by the "Hirst model" for both "total production" (adults + juveniles) and "juvenile production". Mean production followed the same pattern

\section{Table 5}

Mean density (individuals $\mathrm{m}^{-3}$ ) of individuals at different developmental stages (C: copepodites; N: nauplii) for each sampling site (SS) and season (WI: winter; SP: spring; SU: summer; AU: autumn) collected with nets of different mesh size (NM: 200 and $90 \mu \mathrm{m}$ ) in the Patos Lagoon estuary (Rio Grande, RS, Southern Brazil). EM: estuary mouth; ME: Mangueira enclosure; NC: navigation channel; WM: west margin of the estuary; YC: Yatch Club enclosure.

\begin{tabular}{|c|c|c|c|c|c|c|c|c|c|c|c|}
\hline \multirow{2}{*}{$\frac{\mathrm{SS}}{\mathrm{NM}}$} & & \multicolumn{2}{|c|}{ EM } & \multicolumn{2}{|c|}{ ME } & \multicolumn{2}{|c|}{$\mathrm{NC}$} & \multicolumn{2}{|c|}{ WM } & \multicolumn{2}{|c|}{ YC } \\
\hline & & 200 & 90 & 200 & 90 & 200 & 90 & 200 & 90 & 200 & 90 \\
\hline \multirow[t]{2}{*}{ WI } & $C$ & 2368 & 1076 & 13,977 & 13,453 & 3296 & 2878 & 3939 & 4020 & 4054 & 1005 \\
\hline & $\mathrm{N}$ & 0 & 4305 & 932 & 6115 & 0 & 1245 & 0 & 3544 & 0 & 905 \\
\hline \multirow[t]{2}{*}{ SP } & $C$ & 7616 & 1349 & 7333 & 287 & 210 & 208 & 381 & 1080 & 105 & 324 \\
\hline & $\mathrm{N}$ & 55 & 372 & 333 & 2156 & 6 & 375 & 0 & 170 & 2874 & 180 \\
\hline \multirow[t]{2}{*}{ SU } & $C$ & 128 & 516 & 387 & 1036 & 158 & 213 & 86 & 593 & 874 & 1143 \\
\hline & $\mathrm{N}$ & 0 & 1793 & 0 & 1461 & 0 & 1340 & 0 & 2343 & 0 & 1543 \\
\hline \multirow[t]{2}{*}{ AU } & $C$ & 52 & 212 & 377 & 201 & 141 & 294 & 0 & 76 & 0 & 63 \\
\hline & $\mathrm{N}$ & 69 & 3434 & 152 & 3289 & 0 & 1324 & 81 & 3652 & 27 & 3043 \\
\hline
\end{tabular}




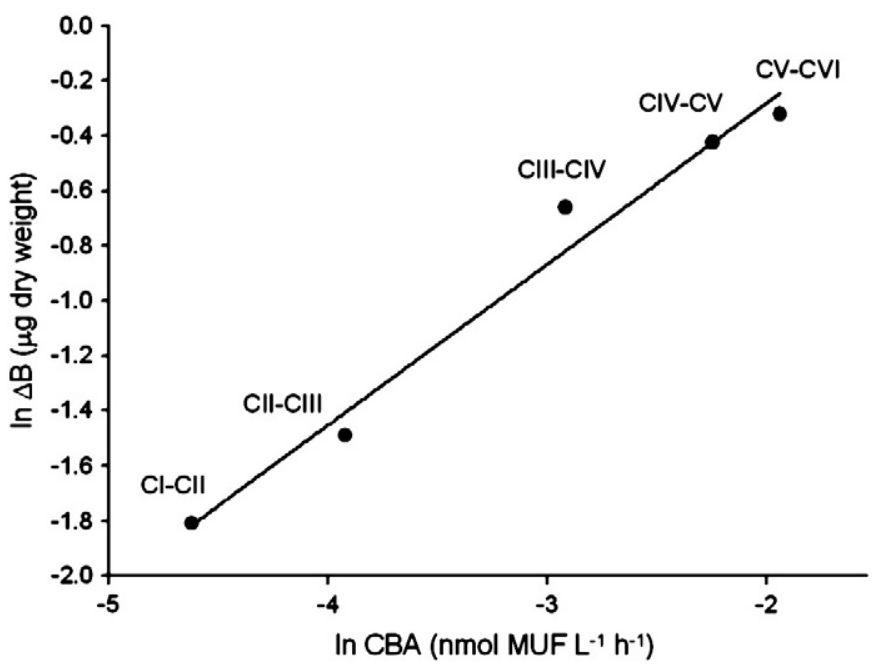

Fig. 2. Relationship between the natural logarithm of the increment in dry weight from the stage $x$ to the stage $x+1(\ln \Delta \mathrm{B})$ and the activity (nmol MUF $\mathrm{L}^{-1} \mathrm{~h}^{-1}$ ) of chitobiase (CBA) released during the molting process of Acartia tonsa copepodites (CI-CVI).

showed by biomass, the higher values being estimated from data collected with the 200- $\mu \mathrm{m}$ mesh net in winter and spring. The higher value of mean production was observed in winter ( $4.35 \mathrm{mg} \mathrm{C} \mathrm{m}^{-3} \mathrm{day}^{-1}$ ) and decreasing in the other seasons, disregarding the mathematical model employed or the net mesh used for zooplankton collection. The lower value of mean production (0.05 $\mathrm{mg} \mathrm{C} \mathrm{m}^{-3} \mathrm{day}^{-1}$ ) was observed in autumn (Table 4).

Considering the production data estimated based on the analyses of zooplankton collected at each estuarine sampling site and using mathematical models, the higher total production calculated using the "Huntley model" was observed at the ME site $\left(9.2 \mathrm{mg} \mathrm{C}^{-3}\right.$ day $\left.^{-1}\right)$ in spring. For the "Hirst model", the higher total production was also found at the ME site, but in winter $\left(7.9 \mathrm{mg} \mathrm{C} \mathrm{m}^{-3} \mathrm{day}^{-1}\right)$. Using the enzymatic method, high values of total production were also observed at the $\mathrm{ME}$ site in spring $\left(11.0 \mathrm{mg} \mathrm{C} \mathrm{m}^{-3} \mathrm{day}^{-1}\right)$ and winter $\left(12.5 \mathrm{mg} \mathrm{C} \mathrm{m}^{-3} \mathrm{day}^{-1}\right)$. In turn, the lower total production values were estimated in autumn at all sampling sites, being below $1 \mathrm{mg} \mathrm{C} \mathrm{m}{ }^{-3} \mathrm{day}^{-1}$ for both the "Huntley" and "Hirst" models and approximately $2 \mathrm{mg} \mathrm{C} \mathrm{m}^{-3}$ day $^{-1}$ for the chitobiase method (Fig. 4).

Net mesh, mathematical model, and estimation method (mathematical model or enzymatic method) employed were shown to

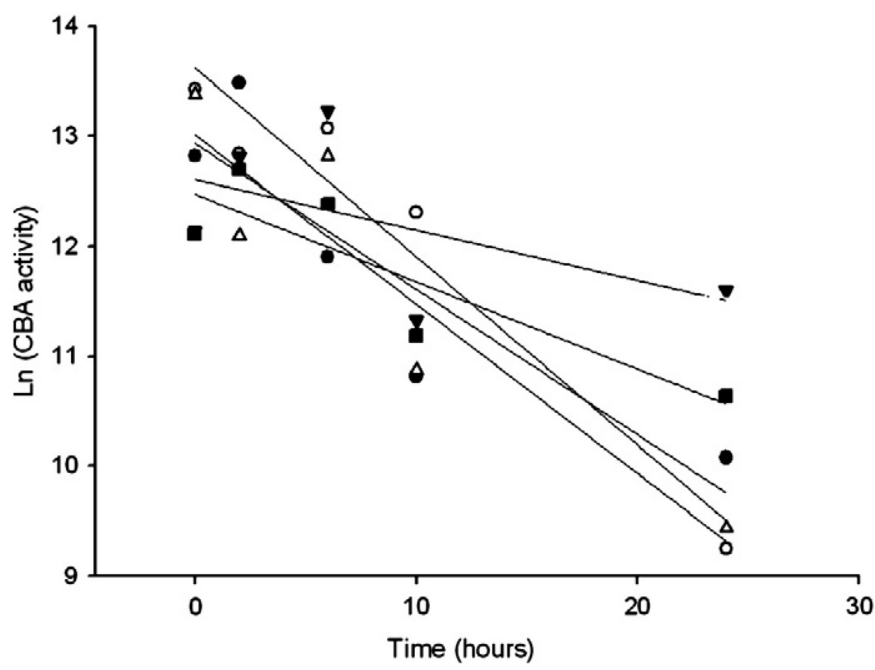

Fig. 3. Decay in chitobiase activity over time for each sampling site of the Patos Lagoon estuary (Rio Grande, RS, Southern Brazil) in spring. — EM: estuary mouth; O ME: Mangueira enclosure; $\nabla$ NC: navigation channel; $\triangle$ WM: west margin of the estuary; $\mathbf{q C}$ : Yatch Club enclosure. influence the results obtained for the zooplankton production estimations. Differences among mean values estimated for the two nets using the same model were higher than those found using the different mathematical models for the same net, as well as those obtained using the chitobiase method in winter. In this case, mean production estimated using the "Huntley model" was $2.55 \mathrm{mg} \mathrm{C} \mathrm{m}^{-3}$ day $^{-1}$ higher for samples collected with the $200-\mu \mathrm{m}$ mesh net than for those collected with the 90- $\mu \mathrm{m}$ mesh net, while the differences between values estimated using the "Huntley model" and the chitobiase method and between the "Huntley model" and the "Hirst model" were only 1.12 and $1.34 \mathrm{mg} \mathrm{C} \mathrm{m}^{-3}$ day $^{-1}$, respectively. In the other seasons, the main factor responsible for the differences observed in production values was the method employed for estimation. In this case, the higher difference ( $4.75 \mathrm{mg} \mathrm{C} \mathrm{m}^{-3}$ day $^{-1}$ ) was found for winter samples when production values were estimated using the "Hirst model" and the chitobiase method (Table 4).

Taking all sampling sites and seasons together, the slope of the regression between the mean production values estimated based on the "Huntley model" and the chitobiase method was not different from $1\left(b=1.12 \pm 0.16 ; n=20 ; R^{2}=0.73 ; p<0.001\right)$. A similar result was found for the regression analysis between data obtained for the "Hirst model" and the chitobiase method $(b=1.21 \pm 0.26 ; n=20$; $\mathrm{R}^{2}=0.55 ; \mathrm{p}<0.001$ ). In all cases, production values estimated based on the enzymatic method were systematically higher than those generated by the mathematical models. The magnitude of this difference corresponded to $1.95 \pm 0.58$ and $2.494 \pm 0.73 \mathrm{mg} \mathrm{C} \mathrm{m}^{-3}$ day $^{-1}$ for the "Huntley model" and the "Hirst model", respectively. These values were derived from the intercept of the regression curves referred above.

\section{Discussion}

In the present study, zooplankton analysis in the Patos Lagoon estuary was performed based on only one collection per sampling site at each season. Despite that, water temperature data obtained during the sampling procedure was similar to the mean values representative of each season (Niencheski et al., 1986). Regarding water salinity, low mean values can be frequently observed in the estuarine waters from Patos Lagoon. However, the extremely low mean values found in all seasons in the present study would result from the influence of the Southern Oscillation phenomenon occurring in the South Pacific (El Niño) during the present study. In fact, this phenomenon causes an increase in the pluviometric index in the whole drainage basin of the Patos Lagoon increasing the freshwater flow through the estuarine area (Fernandes et al., 2002).

The long periods of low water salinity ( $0-4 \mathrm{ppt}$ ) and the volume of freshwater discharged through the estuary mouth prevented the intrusion of coastal marine waters into the estuarine area, influencing the zooplankton composition. The expected presence of the copepod A. tonsa year round did not occur, with organisms appearing only in the winter and autumn when water of salinity 4 ppt was an indicative of some intrusion of coastal waters into the estuary. With the occurrence of waters of low salinity during spring and summer, the freshwater copepod $N$. incompositus replaced the marine copepod $A$. tonsa and the proportion of freshwater cladocerans and cyclopoid copepods increased with respect to that observed in the winter sampling. It is recognized that only one day of collection per season in five sampling sites at the estuarine area would not be enough to determine the pattern of zooplankton composition, biomass and production for each season. However, differences observed among sampling sites and seasons represented the variations existing among habitats, making the conditions ideal to evaluate the effectiveness of the methods employed for secondary production estimations.

Although the Patos Lagoon is one of the major coastal water bodies in the whole of South America, the present paper is the first to report data of zooplankton biomass in this estuary. All taxonomic groups 


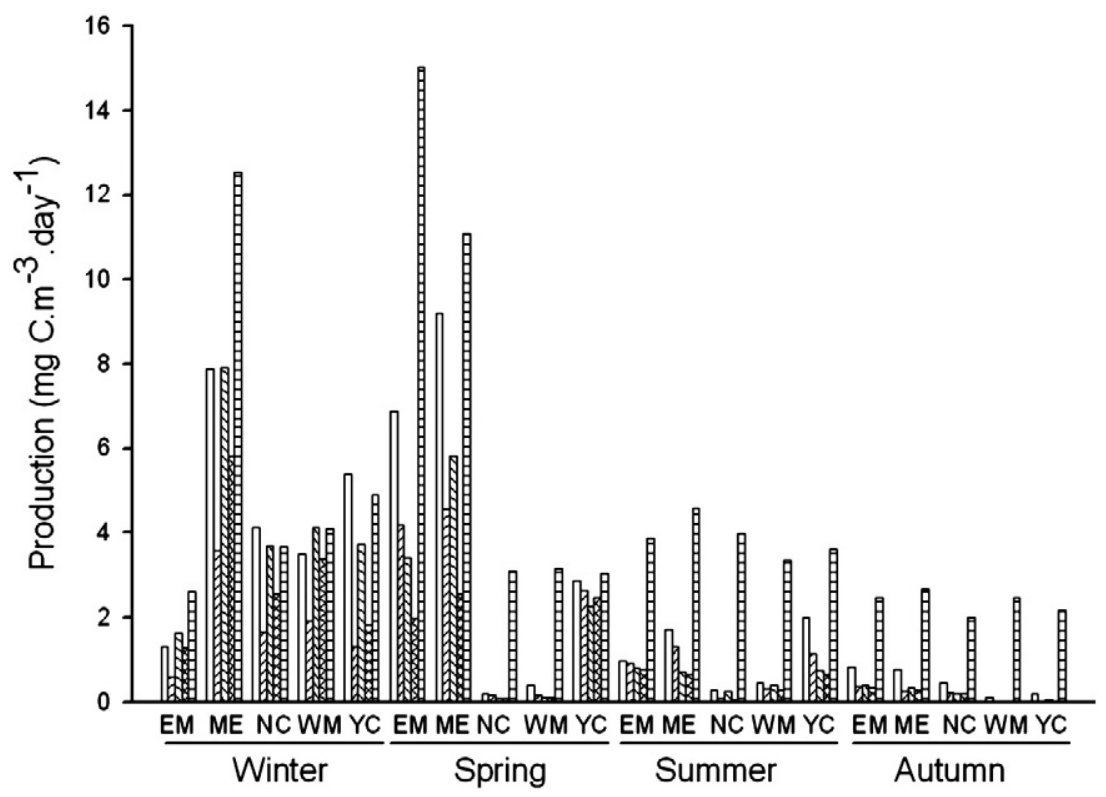

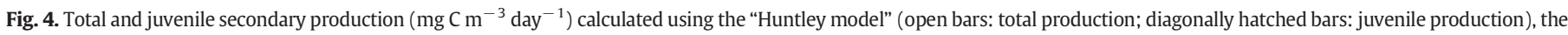

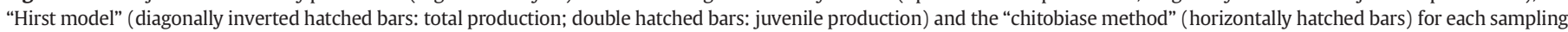
site of the Patos Lagoon estuary (Rio Grande, RS, Southern Brazil) in each season.

present in samples were identified and quantified. However, calculations were based only on crustaceans. In fact, results showed no substantial abundance of other animal groups, as previously reported for other environments with similar characteristics (Lobo and Leighton, 1986). Therefore, values obtained in the present study are representative of the zooplankton total biomass.

With the frequent occurrence of waters of low salinity, a decrease in the total biomass was observed, as in the Tamar estuary (Tasmania) when the peak of biomass $\left(20.5 \mathrm{mg} \mathrm{C} \mathrm{m}^{-3}\right)$ occurred in waters of intermediary salinities and the lower values were found in waters of lower salinities (Lopez and Neira, 2008). Also, an extremely low abundance of organisms was reported in Pensacola Bay when rain events were frequent, causing large discharge of freshwater from rivers into the bay (Murrel and Lores, 2004). The higher values of biomass found in winter $\left(25.29 \mathrm{mg} \mathrm{C} \mathrm{m}^{-3}\right)$ and spring $\left(25.00 \mathrm{mg} \mathrm{C} \mathrm{m}^{-3}\right)$ in the Patos Lagos estuary are similar to the maximum values reported for the Tasmanian (Tamar estuary; $20.5 \mathrm{mg} \mathrm{C} \mathrm{m}^{-3}$ ) and South African (Kariega estuary; $23.72 \mathrm{mg} \mathrm{C} \mathrm{m}^{-3}$ ) estuaries (Froneman, 2001). However, biomass values are lower than those reported for the North American estuaries in Pensacola Bay (34.1 $\mathrm{mg} \mathrm{C} \mathrm{m}^{-3}$ ) (Murrel and Lores, 2004) and Chesapeake Bay (32.4 $\mathrm{mg} \mathrm{C} \mathrm{m}^{-3}$ ) (Park and Marshall, 2000).

Differences in biomass observed among sampling sites on the same day of collection could be explained by considering the dynamic of water circulation in the estuarine area. Circulation causes a higher concentration of organisms in some sectors of the estuary and defines part of the zooplankton composition, as previously discussed by Montú (1980). In turn, differences observed when biomass values were calculated for each taxonomic group using data from samples collected with nets of different mesh are indicative of a significant influence of net selectivity on the results obtained. The different proportions of sizes collected with higher efficiency by each one of the nets employed (90- and $200-\mu$ mesh nets) was reflected in different values of final biomass. In winter, the final biomass of $A$. tonsa was estimated as more than 2-fold higher for samples collected with the $200-\mu \mathrm{m}$ mesh net than with those collected with the 90- $\mu \mathrm{m}$ mesh net. The different selectivity of nets was also evident when we consider the proportion of nauplii and copepodites collected using one or another net. Higher values were obtained with the 90- $\mu \mathrm{m}$ mesh net, as previously reported for a comparison between the 64- and 200- $\mu \mathrm{m}$ mesh nets (Favareto et al., 2009). These findings indicate the need for using more than one type of net (mesh size) during sampling in order to better evaluate the composition of stages and biomass of zooplankton organisms. Since production data resulting from the application of mathematical models are dependent on the biomass values calculated for field samples, changes in these values directly affect the final data of production for both marine copepods and freshwater organisms.

Regarding the enzymatic (chitobiase) method, the relationship between $\triangle \mathrm{B}$ values and activity of chitobiase released in the water during the molting process (CBA) found for the copepod A. tonsa in the present study showed a similar pattern reported for the Copepoda, Mysidacea and Decapoda evaluated by Sastri and Dower (2009). It is also important to note that the relationship between body length and CBA found for A. tonsa in the present study is similar to those reported for the copepod T. longicornis (Oosterhuis et al., 2000) and Cladocera (Espie and Roff, 1995; Sastri and Roff, 2000). These findings indicate that the terms of the equation used to estimate secondary production in the present study ( $\mathrm{P}=\Delta \mathrm{B} / \mathrm{Tcba}$ ) would be valid and reliable.

The methodology employed to estimate the rate of enzyme activity decay over time in the field, and therefore to calculate the Tcba values, was also effective. Results obtained showed an enzyme activity behavior similar to that described by Oosterhuis et al. (2000) and Sastri and Dower (2006, 2009). As only Sastri and Dower (2009) applied the chitobiase method to estimate secondary production in the field, estimations for the Patos Lagoon estuary made in the present study strictly followed the protocol described by these authors. However, the Patos Lagoon estuary shows frequent changes in water salinity, as opposed to the environments previously evaluated. As the chitobiase activity is dependent on water salinity, correction factors were calculated considering the influence of this water parameter on enzyme activity and final data were corrected using experimentally derived factors (Avila et al., 2011), as described above in the Material and methods section. Nevertheless, the enzymatic (chitobiase) method showed to be efficient in estimate crustacean production in the water column, thus its application being indicated for estimation of secondary production also in estuarine waters.

The maximum values of total secondary production calculated in the present study were $12.5,9.2$ and $7.9 \mathrm{mg} \mathrm{C} \mathrm{m}^{-3}$ day $^{-1}$ for the chitobiase method, "Huntley model" and "Hirst model", respectively. These values are comparable to those estimated by Miyashita et al. 
(2009) for the Santos estuarine system (Santos, SP, Southeastern Brazil) with maximum values of 5.4 and $14.3 \mathrm{mg} \mathrm{C} \mathrm{m}^{-3} \mathrm{day}^{-1}$ using the models described by Hirst and Lampitt (1998) and by Huntley and Lopez (1992), respectively. As observed in the present study, the minimum values reported by Miyashita et al. (2009) were also lower than $1 \mathrm{mg} \mathrm{C} \mathrm{m}^{-3}$ day $^{-1}$. Also, minimum and maximum values of 3 and $8 \mathrm{mg} \mathrm{C} \mathrm{m}^{-3}$ day $^{-1}$ for copepod production and of 2.90 and $12.40 \mathrm{mg} \mathrm{C} \mathrm{m}^{-3}$ day $^{-1}$ for total production were reported for the Skagerrak Strait (Peterson et al., 1991) and the Ria de Aveiro estuary (Leandro et al., 2007), respectively. Therefore, results of production found for the Patos Lagoon estuary in the present study are within the range of values reported for the other estuaries mentioned above. However, it is important to note that results reported in the present study were obtained during the occurrence of the El Niño phenomenon, when a significant increase in the flow of freshwater is observed through the estuarine area. Therefore, it is expected that different production values can be found in years when the El Niño phenomenon is not present.

As observed in the present study, differences in the estimation of secondary production values using different methods were also previously reported in the literature. For example, Miyashita et al. (2009) estimated significantly higher production values using the model described by Huntley and Lopez (1992) than when using the model described by Hirst and Lampitt (1998). Leandro et al. (2007) also reported $22 \%$ higher values using the model described by Huntley and Lopez (1992) than when using the model described by Hirst and Bunker (2003). Therefore, differences among the estimation capacity of the mathematical models and the enzymatic method would be also expected. In the present study, the generally higher production values estimated using the chitobiase method could be explained considering different aspects. It is clear that net selectivity directly influences the production values estimated by the mathematical models, as a consequence of the net selectivity effect on the biomass estimation. A "loss of biomass" could have occurred if larger organisms escaped from the net or the smaller ones passed through the mesh net. In both cases, biomass values estimated from collected samples would be underestimated. In the other hand, the enzymatic method considers all the chitobiase present in the water sample. Therefore, it is possible that some copepods that would have contributed to the total chitobiase measured in the water sample had died or been eaten by predators after having released the enzyme. Furthermore, other sources of chitobiase such as benthic crustaceans could be also contributing for the total enzyme measured in the water column. In these cases, the chitobiase method would be overestimating the production values.

It is also important to stress the current lack of a completely accepted method for secondary production estimation. This is a consequence of the variety of factors affecting this analysis, with difficulty to precisely determine the efficiency of each method employed. Therefore, it is not possible to ascertain if one value of production estimated by one of the methods employed in the present study is more reliable than another value estimated using a different method (mathematical model or enzymatic method). However, it is important to consider that the mathematical models were employed in the present study as reliable tools to estimate secondary production in the Patos Lagoon estuary, since these models consider ecologically relevant parameters such as biomass and growth rate, which have been longer studied. In this context, they were also employed in the present study to evaluate the capacity of the enzymatic (chitobiase) method in order to estimate the expected values found based on the mathematical models. According to the results reported in the present study, we can conclude that the application of the enzymatic method is not limited to marine waters (Sastri and Dower, 2009), but can now be extended to estimate secondary production in estuarine areas where the zooplankton community is dominated by crustaceans. As the present study is only the second report on the application of the chitobiase method to estimate secondary production in the field, and the first in estuarine areas, it is suggested that more studies should be performed in both estuarine and marine waters to confirm the reliability of the chitobiase method in estimating the secondary production under changing environmental conditions. It is important to stress that the use of enzymatic method is more practical, less timeconsuming and cheaper than the use of the traditional mathematical models based on growth to estimate crustacean production.

\section{Acknowledgments}

Financial support is acknowledged to the International Development Research Centre (IDRC, Ottawa, Canada), Coordenação de Aperfeiçoamento de Pessoal de Ensino Superior (CAPES - Programa Ciências do Mar, Brasília, DF, Brazil) and the Conselho Nacional de Desenvolvimento Científico e Tecnológico (CNPq - Instituto Nacional de Ciência e Tecnologia de Toxicologia Aquática, Brasília, DF, Brazil). A. Bianchini is a research fellow from the Brazilian CNPq (Proc. \# 304430/2009-9) and supported by the International Canada Research Chair Program from IDRC. We thank Jefferson Turner for English editing. [SS]

\section{References}

Avila, T.R., Machado, A.A.S., Bianchini, A., 2011. Chitobiase of planktonic crustaceans from South Atlantic coast (Southern Brazil): Characterization and influence of abiotic parameters on enzyme activity. J. Exp. Mar. Biol. Ecol. 407, 323-329.

Berggreen, U., Hansen, B., Kiørboe, T., 1988. Food size spectra, ingestion and growth of the copepod Acartia tonsa during development: implications for determination of copepod production. Mar. Biol. 99, 341-352.

Biegala, I.C., Bergeron, J.P., 1998. Optimal assay conditions for aspartate transcarbamylase (ATCase) activity in mesozooplankton. J. Plankton Res. 20, 1205-1218.

Bradford-Grieve, J.M., Markhaseva, E.L., Rocha, C.E.F., Abiahy, B., 1999. In: Boltovskoy, D. (Ed.), Copepoda. : South Atlantic Zooplankton, v.2. Backhuys Publishers, Leiden, pp. 869-1098.

Espie, J.P., Roff, J.C., 1995. A biochemical index of duration of the molt cycle for planktonic Crustacea based on the chitin-degrading enzyme, chitobiase. Limnol. Oceanogr. 40, 1028-1034.

Favareto, L.R., Perbiche-Neves, G., Serafim-Júnior, M., Sartori, L.P., 2009. Selectivity of plankton nets over planktonic Copepoda in two sub-tropical estuaries. Acta Limnol. Bras. 21, 67-77.

Fernandes, E.H.L., Dyer, K.R., Moller, O.O., Niencheski, L.F.H., 2002. The Patos Lagoon hydrodynamics during an El Niño event (1998). Cont. Shelf Res. 22, 1699-1713.

Froneman, P.W., 2001. Seasonal changes in zooplankton biomass and grazing in a temperate estuary, South Africa. Estuarine Coastal Shelf Sci. 52, 543-553.

Hirst, A.G., Bunker, A.J., 2003. Growth of marine planktonic copepods: global rates and patterns in relation to chlorophyll $a$, temperature, and body weight. Limnol. Oceanogr. 48, 1988-2010.

Hirst, A.G., Lampitt, R.S., 1998. Towards a global model of in situ weight-specific growth in marine planktonic copepods. Mar. Biol. 132, 247-257.

Hirst, A.G., Mckinnon, A.D., 2001. Does egg production represent adult female copepod growth? A call to account for body weight changes. Mar. Ecol. Prog. Ser. 223, 179-199.

Hopcroft, R.R., Roff, J.C., 1998. Zooplankton growth rates: the influence of size in nauplii of tropical marine copepods. Mar. Biol. 132, 87-96.

Huntley, M.E., Lopez, M.D.G., 1992. Temperature-dependent production of marine copepods: a global synthesis. Am. Nat. 140, 201-242.

Ikeda, T., Kanno, Y., Ozaki, K., Shinada, A., 2001. Metabolic rates of epipelagic marine copepods as a function of body mass and temperature. Mar. Biol. 139, 587-596.

Kang, H.K., Kang, Y.J., Chul, P., 2007. Production of Acartia omorii (Copepoda: Calanoida) in Ilkwang Bay, southeastern coast of Korea. J. Mar. Syst. 67, 236-244.

Kimmerer, W.J., 1987. The theory of secondary production calculations for continuously reproducing populations. Limnol. Oceanogr. 32, 1-13

Kleppel, G.S., Frazel, D., Pieper, R.E., Holliday, D.V., 1988. Natural diets of zooplankton off southern California. Mar. Ecol. Prog. Ser. 49, 231-241.

Leandro, S.M., Morgado, F., Pereira, F., Queiroga, H., 2007. Temporal changes of abundance, biomass and production of copepod community in a shallow temperate estuary (Ria de Aveiro, Portugal). Estuarine Coastal Shelf Sci. 74, 215-222.

Lobo, E.A., Leighton, G., 1986. Estructuras comunitarias de las fitocenosis planctónicas de los sistemas de desembocaduras de rios y esteros de la Zona Central de Chile. Rev. Biol. Mar. 22, 1-29.

Lopez, A.L., Neira, F.J., 2008. Synchronicity between zooplankton biomass and larval fish concentrations along a highly flushed Tasmanian estuary: assessment using net and acoustic methods. J. Plankton Res. 30, 1061-1073.

Magalhães, A., Costa, R.M., Liang, T.H., Pereira, L.C.C., Ribeiro, M.J.S., 2006. Spatial and temporal distribution in density and biomass of two Pseudodiaptomus species (Copepoda: Calanoida) in the Caeté River estuary (Amazon region - north of Brazil). Braz. J. Biol. 66, 421-430. 
McCauley, E., 1984. The estimation of the abundance and biomass of zooplankton in samples. In: Downing, J.A., Rigler, F.H. (Eds.), A manual on Methods for the Assessment of Secondary Productivity in Freshwater. Blackwell, Oxford, pp. 228-265.

Miyashita, L.K., Junior, M.M., Lopes, R.M., 2009. Estuarine and oceanic influences on copepod abundance and production of a subtropical coastal area. J. Plankton Res. 31, 815-826.

Möller, O.O., Casting, P., Salomon, J.C., Lazure, P., 2001. The influence of local and non local forcing effects on the subtidal circulation of Patos Lagoon. Estuaries 24, 297-311.

Montú, M., 1980. Zooplâncton do estuário da Lagoa dos Patos I. Estrutura e variações temporais e espaciais da comunidade. Atlantica 4, 53-72.

Montú, M.A., Gloeden, I., 1986. Atlas dos Cladocera e Copepoda (Crustacea) do Estuário da Lagoa dos Patos (Rio Grande, Brasil). Nerítica 1, 1-134.

Murrell, M.C., Lores, E.M., 2004. Phytoplankton and zooplankton seasonal dynamics in a subtropical estuary: importance of cyanobacteria. J. Plankton Res. 26, 371-382.

Niencheski, L.F., Baptista, J.R., Hartmann, C., Filmann, G., 1986. Caracterização hidrológica de três regiões distintas no Estuário da Lagoa dos Patos - RS. Acta Limnol. Brasil. 1, 47-64.

Oosterhuis, S.S., Baars, M.A., Klein Breteler, W.C.M., 2000. Release of the enzyme chitobiase by the copepod Temora longicornis: characteristics and potential tool for estimating crustacean biomass production in the sea. Mar. Ecol. Prog. Ser. 196, 195-206.

Park, G.S., Marshall, H.G., 2000. Estuarine relationships between zooplankton community structure and trophic gradients. J. Plankton Res. 22, 121-135.

Peterson, W.T., Tiselius, P., Kiorboe, T., 1991. Copepod egg production, moulting and growth rates, and secondary production, in the Skagerrak in August 1988. J. Plankton Res. 13, 131-154.
Postel, L., Fock, H., Hagen, W., 2000. Biomass and abundance. In: Harris, R.P., Wiebe, P.H., Lenz, J., Skjoldal, H.R., Huntley, M. (Eds.), ICES Zooplankton Methodology Manual. Academic Press, San Diego, pp. 83-192.

Purcell, J.E., White, J.R., Roman, M.R., 1994. Predation by gelatinous zooplankton an resource limitation as potential controls of Acartia tonsa copepod populations in Chesapeake Bay. Limnol. Oceanogr. 39, 263-278.

Rigler, F.H., Downing, J.A., 1984. A Manual on Methods for the Assessment of Secondary Productivity in Fresh Waters. Blackwell Scientific, London.

Sastri, A.R., Dower, J.F., 2006. Field validation of an instantaneous estimate of in situ development and growth for marine copepod communities. Can. J. Fish. Aquat Sci. 63, 2639-2647.

Sastri, A.R., Dower, J.F., 2009. Interannual variability in chitobiase-based production rates of the crustacean zooplankton community in the Strait of Georgia. Mar. Ecol. Prog. Ser. 388, 147-157.

Sastri, A.R., Roff, J.C., 2000. Rate of chitobiase degradation as a measure of development rate in planktonic Crustacea. Can. J. Fish. Aquat. Sci. 57, 1965-1968.

Sprugel, D.G., 1983. Correcting for bias in log-transformed allometric equations. Ecology 64, 209-210.

Stockwell, J.D., Johannsson, O.E., 1997. Temperature-dependent allometric models to estimate zooplankton production in temperate freshwater lakes. Can. J. Fish. Aquat. Sci. 54, 2350-2360. 